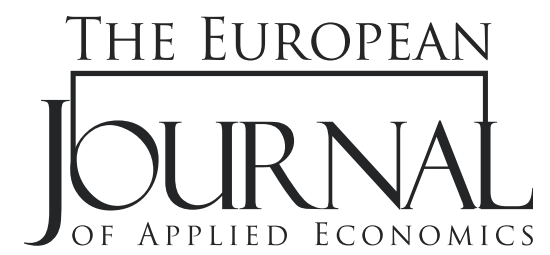

EJAE 2021, 18(1): 151 - 172

ISSN 2406-2588

UDK: $336.748 .3(4-672 \mathrm{EU})$

338.23:336.74

DOI: $10.5937 /$ EJAE18-28714

Original paper/Originalni naučni rad

\title{
DOMESTIC CONSUMPTION AND UNCERTAINTY OF EXCHANGE RATE IN A MONETARY UNION: EVIDENCE FROM THE EURO AREA
}

\author{
Samuel N. Okafor*, Juste S. Lokossou \\ BaumTenpers Theoretical and Empirical Research Group, \\ Lagaos, Nigeria
}

\begin{abstract}
:
The research seeks to uncover how real consumption reacts to real exchange rate uncertainty in the short and long run for the world's largest monetary union- the euro zone. Twelve euro zone countries were sampled covering the period 1995Q1-2019Q4. Using generalized autoregressive conditional heteroskedasticity (GARCH) and pooled mean group (PMG), the result shows that exchange rate uncertainty significantly dampens long-run consumption while the short-run effect is mixed. In the benchmark model, a negative and significant error correction coefficient was obtained, which allows to argue that i) there is evidence of a return to the long-run equilibrium path for consumption following short run deviations and ii) the speed of adjustment to equilibrium is low, with a coefficient of $\sim 4 \%$. This suggests that, in the euro zone, convergence to long-run equilibrium is slow, as the proportion of disequilibrium corrected in one quarter, following a shock, is about $4 \%$, which implies it would take $\sim 17$ quarters for one half of the disequilibrium, or deviations from the long-run consumption path to become corrected.
\end{abstract}

\section{Article info:}

Received: October 5, 2020

Correction: October 22, 2020

Accepted: March 8, 2021

\section{Keywords:}

Monetary union, euro zone, exchange rate, consumption, uncertainty, GARCH, PMG.

\section{JEL Classification:} E20, E21

\section{INTRODUCTION}

In January 1999, the final stage in the introduction of the European Economic and Monetary Union was initiated and subsequently completed, giving rise to the euro zone, which is a group of 19 European countries that have adopted the euro as their common currency, sole legal tender and constitute the largest monetary union in the world. This economic integration formed a unified market for goods and services, labor and capital. These countries began to enjoy seamless trade integration in addition to "import" credibility and stability, often leading to increased investment flows and lower inflation (Hegerty, 2020). 
Consequent upon this event, several studies have been examining the economic structures and macroeconomic outcomes of this union to determine how the economies of member countries have fared over time. However, one important question, which remains unanswered, is how real consumption responds to exchange rate uncertainty in the euro zone. Studies have been carried out on the impact of exchange rate volatility on domestic consumption in individual countries (Kumar, Bhutto, Mangrio, \& Kalhoro, 2019; Njindan Iyke \& Ho, 2018; Bahmani-Oskooee \& Xi, 2012, Mumtaz \& Ali, 2020; Ang (2011); Rangvid et al., 2016; Aye \& Harris, 2019). Studies in the empirical macroeconomics literature have also employed panel-based techniques to determine volatility impact of real exchange rate on real domestic consumption for panels of countries that cut across different regions, continents, or a combination of both (Oseni, 2016; Bahmani-Oskooee, \& Xi, 2011; Bahmani-Oskooee, \& Hajilee, 2012; Mohsen Bahmani-Oskooee \& Baek, 2020; Kodama, 2013; Bahmani-Oskooee, Halicioglu \& Neumann, 2018), but not much is known about the impact that real exchange rate uncertainty has on real domestic consumption in a large monetary union such as the euro area.

In this paper, we present an empirical analysis of the macroeconomic impact on real domestic consumption of uncertainty in real exchange rate in the euro zone. This enables us to fill the identified existing gap in the literature. The euro zone experienced the effects of the global financial crisis in addition to the euro zone crisis, so, both crises are taken into account to prevent bias by including them in the model specification as extra predictor variables where 1 and 0 represent the occurrence and absence of crisis throughout the quarters respectively. The results suggest that the negative long run effect of uncertainty on real consumption in the euro zone remains unchanged even after controlling for these two crisis periods.

There are several reasons to have focused on the euro zone in this paper. Firstand most importantly, the euro zone is the largest and most economically prosperous monetary union in the world. In a monetary union, one of the key advantages is risk and uncertainty sharing and an improved adjustment mechanism that acts as a shock absorber within the currency area. Some of these mechanisms include higher mobility of production factors such as labor, capital (Šovran \& Hadžić, 2016) and technological transfers, together with centralized monetary policy and fiscal transfers between different parts of the union. Since risks and uncertainty are shared in a monetary union, then a plausible hypothesis is that any harmful effect of uncertainty on real consumption could be muted, limited or at worst equally shared. This potentially explains the mixed result obtained for short run in the euro area where, although there is evidence of a negative consumption effect of uncertainty, the impact can also be positive.

Second, an optimal monetary union which functions for optimal currency areas often have integrated capital markets. These integrated capital markets ensure the ease of capital flows among member countries, diminished transaction costs and lower valuation effects, given the adoption of a single currency. Therefore, in the event of negative labor market outcomes in some member countries that lead to reduced income, real consumption may not necessarily collapse as the better-performing parts of the union might generate adequate returns on invested capital that agents can use to support consumption. This outcome, which is plausible for countries in an optimal monetary union, is largely not existent for panels of countries that do not constitute a monetary union. Hence, it is possible for real consumption in a monetary union to respond differently to shocks compared to their non-monetary union counterpart. Despite this insight, most studies examining the response of real consumption to macroeconomic shocks have concentrated on countries that are not in a monetary union and nothing is known about the responses of real consumption to macroeconomic outcomes in a monetary union. This paper addresses this gap in the literature. 
Third, compared to countries which have been studied in the literature, the euro zone, as a centralized monetary policy union, is generally not subject to concentration risk. Therefore, an economic slowdown that could dampen lending by financial institutions to the private sectors in the non-monetary unions, due to a fear of default, may in fact go hand-in-hand with more lending as the integrated financial markets continue to ensure that cross border financial institutions operating in better performing parts of the union can extend credit to worthy and more productive borrowers in the parts experiencing a slowdown,.This can possibly lead to a positiverather than a negative convergence in real consumption in the region, resulting in a different outcome for real consumption in the euro zone, at least in the short run. Itis consistent with the mixed outcomes on the short run effects of uncertainty on consumption obtained in this paper. This, again highlights why real consumption of countries in a major monetary union like the euro zone deserves a special focus as their economic outcomes may not necessarily coincide with countries that do not form a monetary union.

These three reasons motivate the resolve to address the novel question of determining how real consumption responds to macroeconomic uncertainty in the euro-zone. Hence, this research aims to investigate the impact of macroeconomic uncertainty on real consumption both on short- and long-term basis in the euro-zone. In line with this, the null research hypothesis (H0) infers that there is no significant impact of macroeconomic uncertainty on real consumption both in the short and long run for the euro-zone; while the alternative hypothesis (H1) submits that there is significant impact of macroeconomic uncertainty on real consumption both in the short and long run for the eurozone. To the researchers' best knowledge, the specific research question and focus on the largest monetary union, the euro-zone, is new in the context of the euro area and thus, constitutes an important contribution to the literature that examines the response of real consumption to real exchange rate uncertainty and the evolution of other macroeconomic variables in the euro-zone.

A brief review of the literature is now provided below.

\section{REVIEW OF LITERATURE}

Scholars have identified consumption as the most important component of demand based on several studies that analyze income, inflation and interest rate as determinants of consumption. In support of interest rate as a determinant of consumption, Bloom (2014) argued that high interest rates have an indirect relationship with investment which slows down economic activities and reduces aggregate consumption in the economy. Bahmani- Oskooee et al. (2015) also added that, the rate of exchange and its volatility are also significant determinants of consumption. Tang (2020) considered exports composition in relation to economic growth in Central and Eastern Europe. Meanwhile, Pham and Nasir (2016) investigated consumption in terms of luxury products and counterfeit markets in UK. Boguth and Lars (2013) through a cross-sectional test revealed that consumption volatility exposure is an adverse key source of risk. In the existing literature, Bernard and Ho (2019) is among the few papers that incorporated both short and long run effect into the analysis. They employed quarterly data from 1993Q1 to 2017Q4 using pooled mean group, mean group, dynamic fixed-effect, Hausman test, GARCH, Dynamic Ordinary Least square and error-corrections. The authors found that exchange rate uncertainty exerts significant detrimental influence on long-run domestic consumption; however, the short-run impact is insignificant. Among the Asian countries considered in Bahmani-Oskooee, Akhtar, Ullah and Majeed (2020), only the Philippines was exempted from short run volatility effects on import, whereas, Pakistan, Malaysia and India continued to experience the effects in the long term. 
Furthermore, they also found a mixed effect among some countries in the long term, however, countries like Pakistan, Malaysia and India showed a more significant coefficient. Arize et al. (2017) investigated the impact of real effective exchange rate on the trade balance of eight countries using different nonlinear techniques with an emphasis on the family of nonlinear auto-regressive distributed lag (NARDL) estimators. Through their approach, they showed evidence that depreciation when separated from appreciation has strong influence on trade balance by asymmetric model. Köse \& Aslan (2020) analyzed the connection of exchange rate uncertainty and foreign trade performance in Turkey using structural vector autoregressive models (SVAR) with the usual restrictions. They found that domestic income and import strongly influenced export above exchange rate volatility.

Similarly, Aliyu (2010) investigated the impact of exchange rate volatility on export trade in Nigeria using monthly data for the period 1997 - 2016. The study established an indirect relationship between exchange rate volatility and export trade in Nigeria. Using the nonlinear ARDL approach, Okwu, Akpa, Oseni and Obiakor (2020) investigated the short and long run effect of oil export revenue and exchange rate on households' consumption expenditure in Nigeria from 1981 to 2016. In their study, they found that exchange rate exerted significant positive effect on consumption both in the short and long run.

Adewuyi and Akpokodje (2013) also documented that exchange rate volatility on consumption in Africa from 1986 to2011, was significant positive and significant negative for anticipated and unanticipated depreciation, respectively. Pavlidis, Paya and Peel (2015) examined 14 OECD economies in a nonlinear framework, and rejected the null of no Granger causality from real exchange rate to real consumption. Johannes et al (2016) analyzed the effect of parameter by modeling uncertainty upon beliefs of U.S postwar aggregate consumption dynamics, and documents that confounded learning due to realistic high-dimensional learning problems, resulting in huge uncertainty over consumption dynamics that recedes gradually. Asteriou, Masatci and Pilbeam (2016) studied the short- and long-run impact of nominal and real exchange rate uncertainty on the trade volumes of MINT countries, using GARCH and ARDL techniques. They found that volatility affects import and export demands for all countries considered, apart from Mexico (in the short run) and Turkey (in the long run).

Latief \& Lefen (2018) analyzed the impact of exchange rate volatility on trade and FDI in seven developing nations along "One Belt and One Road" initiative. The authors discovered that exchange rate volatility significantly hurts trade and FDI inflows. Blagov (2019) while primarily analyzing the effects of exchange rate uncertainty on import firms' pricing behavior in the euro area, noted that exchange rate uncertainty is a key influencer of import prices in the euro area, thus, showing that increased level of exchange rate uncertainty dampens import prices on average, and that the fall is basically orchestrated by the decreased prices of intermediate goods. Kim (2017) while studying the possible impact of exchange rate volatility on Seaborne Import Volume, discovered that exchange rate created a unidirectional causality on both import volume and real income. Besides a long run causality effect on import volume, there also exists a bidirectional causality between exchange rate and exchange rate volatility.

In Olomola and Dada (2017), effect of real exchange rate and exchange rate volatility on trade balance in Sub-Saharan African countries were analyzed. The authors observed that volatility of real exchange rate encouraged trade balance in Sub-Saharan Africa and suggested that the region should utilize the positive relationship in enhancing their trade balance. Similarly, Dada (2017) examined the causal relationship between exchange rate volatility and trade balance in 13 sub-Saharan African countries from 2000-2015. The study emphasized the importance of exchange rate volatility in determining trade balance in sub-Saharan African countries. In the same vein, Nadir (2017) estimates the effect of exchange rate volatility on the international trade in Uzbekistan from 1999 to 2009. 
Aydin (2010) investigates panel data for 182 countries from 1973 to 2008 and finds different dynamics in the impact of macroeconomic fundamentals on the equilibrium real exchange rate of subSaharan African economies compared with less advanced economies. The study documented that the real exchange rate volatility has a substantial impact on the exports and imports of Uzbekistan during the period. Herve, Yao and Amzath (2010) examined the effect of real exchange rate on the balance of trade of Cote d'Ivoire from 1975 to 2007 using multivariate cointegration tests. Their results showed that real exchange rate has a significant positive influence on Cote d'Ivoire's trade balance in both short and long run under fixed real exchange rate management policies for the observed period.

Al-Abri and Baghestani (2015) studied the impact of greater foreign investment on real exchange rate volatility, and found that greater stocks of foreign liabilities discouraged real exchange rate volatility in China, India, Malaysia, Singapore, and South Korea but encouraged real exchange rate volatility for Indonesia, Philippines, and Thailand. Yaya and $\mathrm{Lu}$ (2012) examined the causality between effective exchange rate and balance of trade in China with Granger causality test using monthly data from January 1994 to August 2009. The result revealed that in the short run, balance of trade causes a change in effective exchange rate but not vice versa. Bachmann, Elstner, and Sims (2013) examined the behavior of monthly uncertainty proxies and their relationships with other proxies for uncertainty adopted in the literature while cross examining the popular "wait and see" effect of uncertainty on economic activities of Germany and the US. In Soleymani and Chua (2014), the effect of exchange rate volatility was investigated on industry trade flows between Malaysia and China. The authors found that exchange rate uncertainty had positive effect on most of the industries. Bondt, Giesek, and Tujula (2020), assert that wealth increase bolsters households' confidence and shore up consumption. Stating further that the level of household wealth is a strong determinant of choices and growth in the long term. The works of Fernandez-Villaverde et al (2011) showed that volatility of real interest rate has significant effect on consumption and other economic variables such as output, investment and hours in emerging economies. Palumbo, Rudd and Whelan (2002) showed that using their preferred way in accounting for durable goods, their research indicated a considerable strong and stable correlation between consumption and financial wealth, whereas the traditional method produced a weaker relationship. Fostel and Geanakoplos (2012) and Bachmann and Moscarini (2012) proffered theoretical explanations for aggravating higher firm-level uncertainty due to risky behavior that results from bad times. While D'Erasmo and Moscoso Boedo (2012), and Tian (2012) suggested other possible influencers of endogenously countercyclical uncertainty.

A few studies have focused their attention on components influencing consumption and savings decisions since they in turn influence decisions on fiscal and monetary policies. The expanse of data on consumption is attributed primarily to the importance of consumption and saving decisions which are key components in economic analysis both in the short and long run. For instance, monetary policy decisions in the short run are subject to the consumption level affecting the business climate. Furthermore, Tedongap (2015) discovered that changes in consumption volatility are mainly responsible for describing the anomalies associated with asset pricing across risk horizons. Several studies have identified consumption as the most important components of demand based on several studies which highlighted income, inflation and interest rate as consumption determinants. In Obstfeld and Rogoff (1998), exchange rates were found to inhibit real consumption in different forms, directly and indirectly. Their perspective on direct form is that agents such as households and firms generally respond negatively to uncertainty, and this response shapes their consumption patterns. Moreover, consumption is also affected by production, trade and income uncertainties. For the indirect form, they posited that real consumption may be hindered, as firms tend to lessen exposure to risks associated with uncertainty in exchange rates through upward reviews of prices. 
In Kugler (1985), inflation rate, interest rate and income rate were used as explanatory variables for consumption of nondurables in four developed countries. Bahmani-Oskooee, Kutan and Xi (2015) ascertained whether uncertainty of exchange rate impedes consumption in selected emerging economies. The selected countries included Armenia, Bolivia, Bulgaria, Chile, Colombia, the Czech Republic, Hungary, Malaysia, the Philippines, Poland, Russia and South Africa. The estimation technique utilized were GARCH and error correction model, using quarterly data which covered periods from 1991Q1 to 2014Q4. The study postulated that domestic consumption in most of the economies sampled was influenced by exchange rate uncertainty in the short-run but sustained long run effect was noticeable in half of the economies.

In recent times, exchange rates have begun to gain prominence in the literature as one of the key drivers of consumption due to increase in trade openness among countries (Iyke \& Ho, 2018). Not many researchers analyzed exchange rate's volatility effect in relation to real consumption. Furthermore, by focusing on only the long-run effects, they tend to undermine the short-run persistence and adjustment to equilibrium. Our paper fills this by assessing the impact of exchange rate uncertainty over real consumption of twelve countries in the euro area and accounting for both short- and long-run effects. These countries are Austria, Belgium, Finland, France, Germany, Greece, Ireland, Italy, the Netherlands, Portugal, Slovakia, and Spain. While this paper examines the effect of exchange rate volatility on real consumption as in the previous studies, it differs from these studies in several important ways. First, it provides answers to the question on minimal and extended run impact which the volatility of exchange rate bears consumption in euro zone, a large and important monetary union which, surprisingly, previous studies have overlooked. Second, it performs robustness analysis that accounts not only for the Global Financial Crisis as in Iyke and Ho (2019), but also accounts, more importantly, for the euro zone crisis that occurred from Q3 2009 to Q2 2013 and affected the economic fortunes of euro area member countries. Hence, the study implements systematically an additional robustness check to see if the benchmark analysis remains true even after controlling for the euro zone crisis.

\section{METHODOLOGY}

This study employed both the Mean Group and Pooled Mean Group approach for a panel of twelve countries to study impacts of exchange rate volatility on the Euro-zone while considering the short and long run effects. These countries include Austria, Belgium, Finland, France, Germany, Greece, Ireland, Italy, the Netherlands, Portugal, Slovakia, and Spain. Data for the twelve countries were sourced from the Federal Reserve Economic Data (FRED) and are based on data availability as these are the euro zone countries for which complete data for the variables in this analysis are available in the periods from 1995Q1 to 2019Q4.

In the literature, studies such as Mankiw (1991), Campbell and Palumbo et al. (2002), Kandil and Mirzaie (2011) and Iyke and Ho (2019) have shown that real income and interest rate are important determinants of real consumption. Therefore, these variables are included in the modelling framework.

In the benchmark model, Iyke and Ho (2019) was adopted to measure the uncertainty of exchange rate using (GARCH $(1,1)$ ) model. Accordingly, the benchmark empirical specification for the linear consumption model that will be used to examine the impact of real exchange rate uncertainty (VOL) on real consumption can be expressed explicitly as: 


$$
\ln C_{i t}=a_{0}+a_{1} V O L_{i t}+a_{2} \ln Y_{i t}+a_{3} r_{i t}+e_{i t}
$$

In the above equation, $C_{i t}, Y_{i t}, r_{i t}$ and $V O L_{i t}$ represent the real consumption, real income, real interest rate, and exchange rate uncertainty of country $i=1, \ldots, N$ in the euro zone in quarter $t=1, \ldots, T$, while $\ln$ denotes the natural logarithm operator and $a_{1}, a_{2}$ and $a_{3}$ are the model coefficients to be estimated and, finally, $e_{i t}$ is the random error term.

In the benchmark model, the series for all macroeconomic variables are directly observable, except for the variable $V_{0 L}$ which is not directly observable in itself but represents the estimated series of real exchange rate volatility obtained from a GARCH $(1,1)$ specification in the spirit of Iyke and Ho (2019). For each of the $i=112$ euro zone countries considered, the real exchange rates (expressed in natural logarithms) are used to generate the error terms $\varepsilon_{t}$ which are i.i.d with mean of zero and variance 1 . The time varying conditional variance of $\varepsilon_{t}$, which is of a known form $\sigma_{t}^{2}$, then represents the measure of real exchange rate uncertainty. The square of the lagged estimates of the error terms $\varepsilon_{t}$ (i.e. their lagged square residuals) together with the conditional variance $\sigma_{t}^{2}$ and their lagged values, both enter as inputs into the GARCH $(1,1)$ specification and give rise to the uncertainty variable, $V O L_{i t}$, which represents the GARCH based measure of real exchange rate uncertainty.

More formally, the common logarithm of the real exchange rate for each country adheres to AR (1) process as below:

$$
\ln R E R_{t}=c+\theta \ln R E R_{t-1}+\varepsilon_{t}
$$

where $\ln R E R_{t}$ represents natural logarithm for real exchange rate, $c$ is a constant, $\theta$ is the autoregressive coefficient on the lagged natural logarithm of the real exchange rate and $\varepsilon_{t}$ represent the error terms or i. i. d innovations with mean zero and variance 1. The conditional variance $\sigma_{t}^{2}$ of equation (2) measures uncertainty of real exchange rate, given by $\sigma_{t}^{2}=\operatorname{Var}\left[\varepsilon_{t} \mid \mathcal{F}_{t-1}\right]$, where $\mathcal{F}_{t-1}$ is the $\sigma$-algebra generated by $\ln R E R_{0}, \ldots \ldots, \ln R E R_{t-1}$. Thus, $\sigma_{t}^{2}=\operatorname{Var}\left[\mathcal{E}_{t} \mid \mathcal{F}_{t-1}\right]$. With this information, the GARCH $(1,1)$ model is written as:

$$
\sigma_{t}^{2}=\omega+\delta \varepsilon_{t-1}^{2}+\mu \sigma_{t-1}^{2}, \omega=\gamma \sigma_{L R}^{2} ; \gamma, \delta, \mu>0 \text { and } \gamma+\delta+\mu=1
$$

where $\delta$ and $\mu$ are parameter coefficients to be estimated, $\omega$ is a constant deterministic term representing the lowest value that the conditional variance $\sigma_{t}^{2}$ can achieve in any time period, $\sigma_{I R}^{2}$ is the non-time-varying, unconditional long run variance, and $\gamma$ is some scaling factor such that $\gamma=\omega / \sigma_{L R}^{2}$. Given $\omega, \delta$ and $\mu$ the long-run variance $\sigma_{L R}^{2}$ can be obtained from (3) as $\sigma_{L R}^{2}=\frac{\omega}{1-\delta-\mu}, \delta+\mu<1$.

Note that one function of $\omega$, as a constant deterministic term, is to allow the conditional variance $\sigma_{t}^{2}$ to reach a positive level (as $\omega>0$ ) provided the condition $\delta+\mu<1$ is satisfied.

Two components of volatility were also generated using component GARCH $(1,1)$, which is a variant of the GARCH $(1,1)$ model. The two components resulting from the volatility decomposition of exchange rate volatility are the temporary and permanent components. The temporary component makes it feasible to examine the patterns of short run volatility and how this influences consumption; the permanent component allows for the investigation of the evolution of long run volatility and its impact on consumption. Providing this distinction between the temporary and permanent components of volatility allows one to strategically differentiate the effect of short-term uncertainty on consumption (both in the short and long run) from the effect of long-run uncertainty on consumption (both in the short and long run). 
Following Gutiérrez, Calisto and Salgado (2017), the component GARCH $(1,1)$ which gives rise to the temporary and permanent components of volatility can be written in the form:

$$
\sigma_{t}^{2}=q_{t}+\delta\left(\varepsilon_{t-1}^{2}-q_{t-1}\right)+\mu\left(\sigma_{t-1}^{2}-q_{t-1}\right)
$$

and

$$
q_{t}=\omega+\tau\left(\varepsilon_{t-1}^{2}-\sigma_{t-1}^{2}\right)+\vartheta\left(q_{t-1}-\omega\right)
$$

where $\sigma_{t}^{2}$ in (4) captures the temporary exchange rate uncertainty and indicates the short-term volatility level (temporary component) that reflects near term events such as sentiment-induced innovations, driven by transitory exogenous events, and which undergo cyclical fluctuations. In (5), $q_{t}$ is the long-term volatility level (permanent component) which captures the permanent exchange rate uncertainty and is non-transitory in nature and thus much less influenced by transitory events. Gutiérrez et al. (2017) note that the long-term volatility converges to the unconditional volatility $\omega$ at a level of velocity of $\delta+\mu<\vartheta<1$ while the term $\left(\varepsilon_{t-1}^{2}-\sigma_{t-1}^{2}\right)$ drives the dynamic movement of the longterm volatility. In the temporary component, the difference between the conditional volatility and its long-term volatility $\left(\sigma_{t-1}^{2}-q_{t-1}\right)$ converges to zero at a velocity of $\delta+\mu$.

Finally, we utilize EGARCH $(1,1)$ model as in Nelson (1991) to obtain the volatility required to examine the potentially asymmetric effects of exchange rate uncertainty on consumption. Asymmetric information can be captured in the GARCH $(1,1)$ based measure of exchange rate uncertainty, that is $\sigma_{t}^{2}$. Using an EGARCH $(1,1)$, the uncertainty variable can be modelled thus:

$$
\ln \sigma_{t}^{2}=\omega+\varphi \ln \sigma_{t-1}^{2}+\pi\left|\frac{\varepsilon_{t-1}}{\sigma_{t-1}}\right|+\rho \frac{\varepsilon_{t-1}}{\sigma_{t-1}}
$$

where $\omega, a, \beta$ and $\delta$ are estimable parameters. The model depicts the links between previous shocks and the $\log$ of $\sigma_{t}^{2}$. For a $\beta+\delta$ effect we have a positive shock whereas $\beta$ - $\delta$ effect gives a negative shock. The asymmetry comes into the model as, $\beta \neq \delta$ where $\omega>0, \varphi>0, \pi>0$ and $\pi><=0$ represent the coefficients of the variables. In the exponential GARCH $(1,1$,$) model in (6)$, a positive shock would have an effect of $(\pi+\rho)$ on conditional volatility or exchange rate uncertainty whereas negative shocks have a corresponding impact of $(\pi-\rho)$ on conditional volatility. The potential asymmetry in how uncertainty impacts domestic consumption is captured by the coefficient on the last term, i.e. $\rho$.

An asymmetric effect is said to exist in the model if $\rho \neq 0$. If, in addition, there is evidence that $\rho<0$, then leverage effect is said to exist. Under leverage effect, negative shocks from bad news generate a higher volatility than positive shocks from good news.

The EGARCH $(1,1)$ model thus allows good news (positive shocks) and bad shocks (negative shocks) to have a distinct effect on volatility that in turn could have a distinct effect on consumption.

Having presented the benchmark model specific in equation (1) and described various measures of real exchange rate uncertainty ( VOL) based on GARCH in equations (2) through (6), it is now time to formulate the pooled mean group (PMG) specification of the benchmark specification in equation (1) which would help to recover the short/long run effects of variables of real consumption, together with the corresponding error correction coefficient. Accordingly, equation (1) can be rewritten for panel using a distributed lag model (p, q, $\mathrm{k}$ ) form as follows: 


$$
\ln C_{i t}=\sum_{j=1}^{p} \gamma_{i t} \Delta \ln C_{i t \cdot j}+\sum_{j=0}^{q} \delta_{i j}^{\prime} X_{i t \cdot j}+\mu_{i}+\varepsilon_{i t}
$$

As Pesaran and Shin (1999) argued, it is more convenient to work with a suitable reparameterization of equation (7) above. This is because equation (7), together with the reparameterization, will enable not only the recovery of the long-run effects but also the short-run dynamics. In view of this, equation (7) is reparametrized and reformulated, as an error-correction model for consumption, as follows:

$$
\Delta \ln C_{i t}=e c_{i}\left(\ln C_{i t-j}-\theta_{i} X_{i t}\right)+\sum_{j=0}^{p-1} \gamma_{i j}^{*} \Delta \ln C_{i t-j}+\sum_{j=0}^{q-1} \delta_{i j}^{*} \Delta X_{i t-j}+\mu_{i}+\varepsilon_{i t}
$$

where is $X_{i t}$ a vector of the explanatory variables in the benchmark specification in equation (1); that is, $X_{i t}=\left(V O L_{i t}, \ln Y_{i t}, r_{i t}\right), \mu_{i}$ is the standard country-specific fixed effects and $\varepsilon_{i t}$ is the i.i.d error term.

Furthermore, the other parameters of the specification in equations (7) and (8) are defined as

$$
\begin{aligned}
& e c_{i}=-\left(1-\sum_{j=1}^{p} \gamma_{i t}\right) ; \theta_{i}=\sum_{j=0}^{q} \delta_{i j} /\left(1-\sum_{k} \gamma_{i k}\right) ; \gamma_{i j}^{*}=-\sum_{m=j+1}^{p} \gamma_{i m}, \\
& j=1,2, \ldots . p-1 ; \text { and } \delta_{i j}^{*}=-\sum_{m=j+1}^{p} \delta_{i m}, j=1,2, \ldots q-1
\end{aligned}
$$

where $e c_{i}$ represents the error correction coefficient which depicts the tendency to revert to long run stable equilibrium following a system-wide shock that induces deviations from long run equilibrium to short run. For such convergence or reversion to long run equilibrium to occur, the error correction coefficient $e c_{i}$ should be negative and statistically significant when estimated. Meanwhile, $\theta_{i}$ represents the long run coefficients which show the impact of the variables in the benchmark model of consumption (in the long run).

The adopted specification for this paper has several advantages. On the econometric front, the PMG model is suitable in several scenarios, even in instances where one seeks to study relationships between variables that are $\mathrm{I}(0)$ and variables that are $\mathrm{I}(1)$. Moreover, it is well suited for modelling panels of long dimensions where the time dimension is large or higher than the cross-section, i.e. $\mathrm{T}>\mathrm{N}$, which is the dimension of this data. On the policy front, it captures both the long run impact of exchange rate uncertainty on consumption as well as the short run dynamics. This would help to disentangle long run effect of exchange rate volatility over consumption from the short run effects. One immediate advantage is represented in the additional insights which would help to uncover the type of impact uncertainty has on consumption, - long run versus short run in euro zone. Also, it would allow to formally determine whether there is a reversion to the estimated long run equation after a shock that causes deviations from the estimated long run and to estimate the speed of adjustment to the estimated long run equilibrium in instances where such reversion is plausible. 


\section{EMPIRICAL RESULTS}

\section{Domestic Consumption and Uncertainty of Exchange Rate}

The table presentsthe mean of GARCH based estimate of exchange rate volatility and their corresponding mean consumption for each nation. The parentheses consist of their rank.

Table 1: Summary statistics for exchange rate uncertainty and domestic consumption

\begin{tabular}{lrrrr}
\hline Nation & VOL(Mean) & STDEV(Mean) & Consumption(Mean) & Obs. \\
\hline Austria & $0.008190(12)$ & $0.015792(12)$ & $576,000,000(7)$ & 100 \\
\hline Belgium & $0.012781(9)$ & $0.025872(9)$ & $6,970,000(6)$ & 100 \\
\hline Finland & $0.029127(6)$ & $0.030629(8)$ & $355,000,000(10)$ & 100 \\
\hline France & $0.009619(10)$ & $0.034777(6)$ & $4,140,000,000(2)$ & 100 \\
\hline Germany & $0.015343(8)$ & $0.044135(4)$ & $5,160,000,000(1)$ & 100 \\
\hline Greece & $0.038357(5)$ & $0.035726(5)$ & $443,000,000(8)$ & 100 \\
\hline Ireland & $0.039579(4)$ & $0.077612(2)$ & $267,000,000(11)$ & 100 \\
\hline Italy & $6.566426(1)$ & $0.024937(11)$ & $3,320,000,000(3)$ & 100 \\
\hline the Netherlands & $0.071728(2)$ & $0.034720(7)$ & $1,140,000,000(5)$ & 100 \\
\hline Portugal & $0.008322(11)$ & $0.025218(10)$ & $371,000,000(9)$ & 100 \\
\hline Slovakia & $0.052800(3)$ & $0.173715(1)$ & $126,000,000(12)$ & 100 \\
\hline Spain & $0.020797(7)$ & $0.044359(3)$ & $1,980,000,000(4)$ & 100 \\
\hline All & 0.572756 & 0.047291 & $1,550,000,000$ & 1200 \\
\hline
\end{tabular}

Note: Table 1 shows the summary statistics: the positions or country ranks are in the parentheses. Mean VOL denote the mean of the exchange rate uncertainty measure computed with GARCH and STEV represent estimated standard deviation of exchange rate. Obs is the number of observations. The period covered include 1995Q1 to 2019 Q4.

Table 1 revealed that Italy experienced most uncertainty followed by the Netherlandswhile the least uncertainty is found in Austria (using volatility as proxy for uncertainty). Whereas using standard deviation as proxy for uncertainty, Slovakia experiences the highest uncertainty followed by Ireland while the least was Austria. Highest real consumption (Mean) is noticed for Germany, then France, Italy, Spain, the Netherlands respectively. While the least real consumption (Mean) was found with Slovakia, followed by Ireland and Finland. 


\section{How does Uncertainty of Exchange Rate Influence Domestic Consumption?}

In estimating the benchmark model, GARCH volatility (VOL) has been used as the main baseline to assess exchange rate uncertainty, and common logarithm of consumption as the dependent variable. The benchmark results from the PMG estimation is presented below.

Table 2: Consumption and exchange rate uncertainty (proxy with volatility)

\begin{tabular}{|c|c|c|}
\hline \multicolumn{3}{|c|}{ PMG } \\
\hline Variables & Coefficients & P-value \\
\hline \multicolumn{3}{|c|}{ Long run estimates } \\
\hline In $\mathrm{Y}$ & $0.8570^{* * *}$ & 0.0000 \\
\hline NIR & $-0.0232^{\star * *}$ & 0.0002 \\
\hline VOL & $-0.6117^{\star \star *}$ & 0.0058 \\
\hline \multicolumn{3}{|c|}{ Short-run estimates } \\
\hline ECT & $-0.0441^{\star *}$ & 0.0102 \\
\hline $\mathrm{D}(\operatorname{In} \mathrm{Y})$ & $0.437679^{* * *}$ & 0.0000 \\
\hline $\mathrm{D}(\ln \mathrm{Y}(-1))$ & $0.178158^{\star *}$ & 0.0318 \\
\hline $\mathrm{D}(\ln \mathrm{Y}(-2))$ & 0.110022 & 0.1947 \\
\hline $\mathrm{D}(\ln \mathrm{Y}(-3))$ & $0.119668^{*}$ & 0.0934 \\
\hline $\mathrm{D}(\mathrm{NIR})$ & $-0.003631^{\star * *}$ & 0.0029 \\
\hline $\mathrm{D}(\operatorname{NIR}(-1))$ & 0.000882 & 0.3306 \\
\hline $\mathrm{D}(\operatorname{NIR}(-2))$ & -0.001441 & 0.1945 \\
\hline $\mathrm{D}(\operatorname{NIR}(-3))$ & -0.001692 & 0.2479 \\
\hline $\mathrm{D}(\mathrm{VOL})$ & $1039.379^{\star * *}$ & 0.0094 \\
\hline $\mathrm{D}(\operatorname{VOL}(-1))$ & -0.4273 & 0.5579 \\
\hline $\mathrm{D}(\operatorname{VOL}(-2))$ & $-0.9712^{\star \star \star *}$ & 0.0069 \\
\hline $\mathrm{D}(\mathrm{VOL}(-3))$ & -0.3745 & 0.6737 \\
\hline CONSTANT & 0.159315 & 0.1826 \\
\hline
\end{tabular}

Note: Table shows results of PMG estimation to assess the influence of different measures of exchange rate uncertainty on real consumption. The VOL coefficients are reported as per 1,000 units and $*, * *, * * *$ represent statistical significance, at the $10 \%, 5 \%$ and $1 \%$ level. ECT represents error correction term and D () represents first difference at the different lags. Three lags are chosen.

In Table 2, the error correction parameter estimate [ect] is both significant and acceptable at 5 percent because its value is negative and lies between 0 and 1 . This indicates the presence of steady long run association between the model's variables. Thus, errors generated over the previous period are corrected in the current period, meaning that they come together in the long run if they drift apart in the short run. Both short and long run parameter estimates indicate that uncertainty of exchange rate slows real consumption. It is important to note that the influence of estimated exchange rate uncertainty could be regarded as average effect across the sampled countries. Also, real income significantly enhances consumption in both long and short run. Meaning, a raise in real income would induce an increase in real consumption in both periods. Furthermore, natural interest rates are adversely associated with real consumption (in the long run). 
OKAFOR. N. S., LOKOSSOU. S. J. ^ DOMESTIC CONSUMPTION AND UNCERTAINTY OF EXCHANGE RATE IN A MONETARY UNION:EVIDENCE FROM THE EURO AREA

Table 3: Domestic consumption and exchange rate uncertainty (proxy with standard deviation)

\begin{tabular}{lll}
\hline \multicolumn{1}{l}{ Pariables } & Coefficients & \\
\hline Long run estimates & & P-value \\
\hline In Y & $1.154981^{* * *}$ & 0.0000 \\
\hline NIR & $-0.004841^{* * *}$ & 0.0000 \\
\hline STDEV & $-0.467229^{* * *}$ & 0.0002 \\
\hline Short-run estimates & & \\
\hline ECT & $-0.086719^{* * *}$ & 0.0134 \\
\hline D(In Y) & $0.428757^{* * *}$ & 0.0000 \\
\hline D(NIR) & $-0.002825^{* * *}$ & 0.0012 \\
\hline D(STDEV) & $-0.002725^{* * *}$ & 0.0481 \\
\hline CONSTANT & 0.635683 & 0.1757 \\
\hline
\end{tabular}

Note: Table presents estimated results with standard deviation (STDEV) as alternative measure of uncertainty. ${ }^{*}, * *, * * *$ represent statistical significance, at the $10 \%, 5 \%$ and $1 \%$ level. ECT represents error correction term and D () represents first difference.

\section{Does the Effect of Exchange Rate Uncertainty Depend on the Measure of Uncertainty Employed?}

The error-correction term is acceptable and significant, clearly suggesting that there is convergence. Therefore, there is stable long-run relationship among the variables employed. Clearly, uncertainty reduces real consumption in both short and long run. Comparing baseline (volatility) and alternative measure of uncertainty (standard deviation), exchange rate uncertainty impedes long-run real consumption. Specifically, baseline measure of uncertainty impedes real consumption more than the alternative measure. Thus, the measure of uncertainty adopted is essential in formulating policy on exchange rate uncertainty in the euro zone.

Further evaluation of the effect of exchange rate on uncertainty was estimated using DOLS estimator (dynamic ordinary least squares estimator). But estimation of short run is not permitted in this approach.

Table 4: Dynamic Ordinary Least square (DOL) estimates

\begin{tabular}{lcc}
\hline & Model 1 & Model 2 \\
\hline Variables & Coefficients & \\
\hline In Y & $0.8728^{* * *}$ & $0.82167^{* * *}$ \\
& $(0.0000)$ & $(0.0000)$ \\
\hline NIR & $0.0003^{* * *}$ & $0.0020^{*}$ \\
& $(0.0019)$ & $(0.0863)$ \\
\hline VOL & $-0.4376^{* * *}$ & \\
\hline STDEV & $(0.0000)$ & $-0.3089^{* * *}$ \\
\hline R-Square & & $(0.0000)$ \\
\hline Adj. & & 0.999018 \\
\hline
\end{tabular}

Note: The long-run adverse effect of uncertainty on real consumption is the same in both PMG and DOS techniques irrespective of uncertainty measure adopted. The VOL coefficients are reported as per 1,000 units and $*, * *, * * *$ represent statistical significance, at the $10 \%, 5 \%$ and $1 \%$ level. 
Conclusively, the long run effect of exchange rate uncertainty over real consumption is negative across all countries in the euro zone irrespective of its short run effect in specific country. In the long run, the market conditions are expected to converge. The different market conditions in these countries are a major reason for the inconsistent precarious effect over consumption on the short run. In fact, consumption can be restrained by uncertainty in a country while the effect may be insignificant or cause a rise in consumption for another country within theeuro zone. Bahmani-Oskooee et al. (2015) supported these findings in their study.

\section{Asymmetric Impact of Exchange Rate Uncertainty}

The reactions of economic agents towards unexpected exchange rate alterations are usually different. This denotes that the entire economy may respond in different form to unexpected fluctuations in exchange rate. In fact, one of the spillover effects of negative exchange rate shock is higher uncertainty due to heighten anticipation of increase in speculative risk (Byrne and Davis, 2005).

Hence, GARCH $(1,1)$ model may be inadequate to clearly indicate asymmetric uncertainty. Thus, exponential GARCH (EGARCH) improved on this shortcoming of GARCH $(1,1)$. One major benefit of this technique is that it accounts for positive and negative shocks in conditional variance relating to asymmetries (Nelson, 1991).

Table 5: Effect of asymmetric uncertainty on consumption

\begin{tabular}{|c|c|c|}
\hline \multicolumn{3}{|c|}{ PMG } \\
\hline Variables & Benchmark & Model with EVOL \\
\hline \multicolumn{3}{|c|}{ Long run estimates } \\
\hline In $\mathrm{Y}$ & $\begin{array}{l}0.8570^{* * *} \\
(0.0000)\end{array}$ & $\begin{array}{l}1.2099^{\star * *} \\
(0.0000)\end{array}$ \\
\hline NIR & $\begin{array}{l}0.0232^{\star * *} \\
(0.0002)\end{array}$ & $\begin{array}{l}0.0061^{* * *} \\
(0.0000)\end{array}$ \\
\hline VOL & $\begin{array}{l}-0.61172^{\star * *} \\
(0.0058)\end{array}$ & $\begin{array}{l}-0.65915^{\star * *} \\
(0.0033)\end{array}$ \\
\hline Short-run es & & \\
\hline ECT & $\begin{array}{l}-0.0441^{\star *} \\
(0.0102)\end{array}$ & $\begin{array}{l}-0.0720 \\
(0.1650)\end{array}$ \\
\hline $\mathrm{D}(\operatorname{In} \mathrm{Y})$ & $\begin{array}{l}0.4376^{* * *} \\
(0.0000)\end{array}$ & $\begin{array}{l}0.2686^{\star * *} \\
(0.0465)\end{array}$ \\
\hline $\mathrm{D}(\ln \mathrm{Y}(-1))$ & $\begin{array}{l}0.1781^{\star * *} \\
(0.0318)\end{array}$ & $\begin{array}{l}0.0093 \\
(0.9416)\end{array}$ \\
\hline $\mathrm{D}(\ln \mathrm{Y}(-2))$ & $\begin{array}{l}0.1100 \\
(0.1947)\end{array}$ & $\begin{array}{l}0.0042 \\
(0.9634)\end{array}$ \\
\hline $\mathrm{D}(\ln \mathrm{Y}(-3))$ & $\begin{array}{l}0.1196^{*} \\
(0.0934)\end{array}$ & - \\
\hline $\mathrm{D}(\mathrm{NIR})$ & $\begin{array}{l}-0.0036^{\star * *} \\
(0.0029)\end{array}$ & $\begin{array}{l}-0.0034^{* * *} \\
(0.0018)\end{array}$ \\
\hline $\mathrm{D}(\operatorname{NIR}(-1))$ & $\begin{array}{l}0.0008 \\
(0.3306)\end{array}$ & $\begin{array}{l}-4.7075 \\
(0.8745)\end{array}$ \\
\hline
\end{tabular}




\begin{tabular}{|c|c|c|}
\hline Variables & Benchmark & Model with EVOL \\
\hline \multicolumn{3}{|c|}{ Short-run estimates } \\
\hline \multirow{2}{*}{$\mathrm{D}(\mathrm{NIR}(-2))$} & -0.0014 & $-0.0033^{\star \star}$ \\
\hline & $(0.1945)$ & $(0.0150)$ \\
\hline \multirow{2}{*}{$\mathrm{D}(\operatorname{NIR}(-3))$} & -0.0016 & \multirow{2}{*}{-} \\
\hline & $(0.2479)$ & \\
\hline \multirow{2}{*}{$\mathrm{D}(\mathrm{VOLT})$} & $1.03937^{* * *}$ & -0.02218 \\
\hline & $(0.0094)$ & $(0.4645)$ \\
\hline \multirow{2}{*}{ D(VOLT(-1)) } & -0.42738 & -0.03284 \\
\hline & $(0.5579)$ & $(0.1242)$ \\
\hline \multirow{2}{*}{$\mathrm{D}(\operatorname{VOLT}(-2))$} & $0.971177^{\star * *}$ & -0.025127 \\
\hline & $(0.0069)$ & $(0.3346)$ \\
\hline \multirow{2}{*}{ D(VOLT(-3)) } & 0.37454 & \multirow{2}{*}{-} \\
\hline & $(0.6737)$ & \\
\hline \multirow{2}{*}{ CONSTANT } & 0.1593 & 0.9703 \\
\hline & $(0.1826)$ & $(0.1675)$ \\
\hline
\end{tabular}

Note: Estimated results use the asymmetric measure of uncertainty, EVOL. Table 5 displays the coefficients' estimates. The $\log$ Consumption, InC is the dependent variable. While log of income $(\ln Y)$, log of natural interest rate $(\operatorname{lnNIR})$, and log of volatility (InVOL) are the independent variables. In parentheses are the $p$-values; D and ECT represent the first difference estimator and the error-correction term respectively. The VOLT (that is, VOL and EVOL) coefficients are reported as per 1,000 units and $*, * *, * *$ represent statistical significance, at the $10 \%, 5 \%$ and $1 \%$ level and $D()$ represents first difference at the different lags. Three lags are chosen.

The result shows that the influences of uncertainty on real consumption increase after incorporating the asymmetries effect into the exchange rate uncertainty measure. Other variables exert similar effect as before.

\section{Does Controlling for the Effect of Euro and Global Financial Crisis Influence the Results?}

So far, the study has ignored the occurrence of two major crises - the global financial crisis (2007-2009) and the Euro zoneeuro zone crisis (2009-2013) in the analysis. This is because in the last decade, the euro zone experienced not only the global financial crisis which emanated from the US but also the euro zone crisis which sprang from within. Hence, failing to factor these crises into the empirical analysis might generate spurious and/or biased outcomes. Accordingly, to ensure that the result is not being driven by any of these crises, especially the euro zone crisis, which emanated from the euro area and had notable influence on member countries, these crises were controlled for by sequentially including them in the empirical specification as additional predictor variables. In this section, these crises periods are incorporated into the analysis in order to perform robustness checks to determine whether controlling for these crises periods alters the main results. To do this, a dummy variable was created which takes a value of 1 in any quarter that falls into the crisis period and zero otherwise. The results are presented in Table 6 below. 
Table 6: Consumption and exchange rate uncertainty (controlling for the global financial crisis and Euro financial crisis)

\begin{tabular}{|c|c|c|c|}
\hline \multicolumn{4}{|c|}{ PMG } \\
\hline Variables & Benchmark & Model with GFCDUM & Model with EURODUM \\
\hline \multicolumn{4}{|c|}{ Long run estimates } \\
\hline \multirow{2}{*}{ In $\mathrm{Y}$} & $0.8570^{\star * *}$ & $0.94024^{\star \star \star}$ & $1.2351^{\star * *}$ \\
\hline & $(0.0000)$ & $(0.000)$ & $(0.0000)$ \\
\hline \multirow{2}{*}{ NIR } & $0.0232^{\star * *}$ & $0.033545^{\star * *}$ & $0.0180^{* * *}$ \\
\hline & $(0.0002)$ & $(0.000)$ & $(0.0001)$ \\
\hline \multirow{2}{*}{ VOL } & $-0.61172^{\star * *}$ & $-0.24348^{\star *}$ & $-14.5145^{\star \star *}$ \\
\hline & $(0.0058)$ & $(0.0158)$ & $(0.0021)$ \\
\hline \multicolumn{4}{|c|}{ Short-run estimates } \\
\hline \multirow{2}{*}{ ECT } & $-0.0441^{\star *}$ & $-0.0123^{\star *}$ & $-0.0021^{\star *}$ \\
\hline & $(0.0102)$ & $(0.0456)$ & $(0.0457)$ \\
\hline \multirow{2}{*}{$\mathrm{D}(\operatorname{In} \mathrm{Y})$} & $0.4376^{* * *}$ & $0.4643^{* * *}$ & $0.4148^{* * *}$ \\
\hline & $(0.0000)$ & $(0.0005)$ & $(0.0000)$ \\
\hline \multirow{2}{*}{$\mathrm{D}(\ln \mathrm{Y}(-1))$} & $0.1781^{\star \star}$ & $0.2099^{\star \star}$ & $0.1612^{\star \star}$ \\
\hline & $(0.0318)$ & $(0.0357)$ & $(0.0255)$ \\
\hline \multirow{2}{*}{$D(\ln Y(-2))$} & 0.1100 & 0.1076 & $0.1592^{\star *}$ \\
\hline & $(0.1947)$ & $(0.1919)$ & $(0.0378)$ \\
\hline \multirow{2}{*}{$\mathrm{D}(\ln \mathrm{Y}(-3))$} & $0.1196^{*}$ & 0.1045 & $0.1209^{\star \star}$ \\
\hline & $(0.0934)$ & $(0.956)$ & $(0.0437)$ \\
\hline \multirow{2}{*}{$\mathrm{D}(\mathrm{NIR})$} & $-0.0036^{\star * *}$ & $-0.0036^{\star * *}$ & $-0.0031^{\star \star *}$ \\
\hline & $(0.0029)$ & $(0.0019)$ & $(0.0084)$ \\
\hline \multirow{2}{*}{ D(NIR(-1)) } & 0.0008 & 0.0007 & 0.0006 \\
\hline & $(0.3306)$ & $(0.4207)$ & $(0.3750)$ \\
\hline \multirow{2}{*}{ D(NIR(-2)) } & -0.0014 & -0.001394 & -0.0011 \\
\hline & $(0.1945)$ & $(0.2437)$ & $(0.2772)$ \\
\hline \multirow{2}{*}{ D(NIR(-3)) } & -0.0016 & -0.0018 & -0.0033 \\
\hline & $(0.2479)$ & $(0.1942)$ & $(0.0282)$ \\
\hline \multirow{2}{*}{$\mathrm{D}(\mathrm{VOL})$} & $1.03937^{\star * *}$ & $1.01206^{* * *}$ & 0.651893 \\
\hline & $(0.0094)$ & $(0.0143)$ & $(0.1165)$ \\
\hline \multirow{2}{*}{ D(VOL(-1)) } & -0.427308 & -0.507967 & -0.543261 \\
\hline & $(0.5579)$ & $(0.4471)$ & $(0.4519)$ \\
\hline \multirow{2}{*}{$\mathrm{D}(\operatorname{VOL}(-2))$} & $0.971178^{* * *}$ & $1.01497^{* * *}$ & 0.790107 \\
\hline & $(0.0069)$ & $(0.0065)$ & $(0.6654)$ \\
\hline \multirow{2}{*}{ D(VOL $(-3))$} & 0.374540 & 0.37002 & 0.389401 \\
\hline & $(0.6737)$ & $(0.6628)$ & $(0.6654)$ \\
\hline \multirow{2}{*}{ GFCDUM } & & 0.00307 & \multirow{2}{*}{-} \\
\hline & - & $(0.2977)$ & \\
\hline EURODUM & - & - & -0.010655 \\
\hline \multirow{2}{*}{ CONSTANT } & 0.1593 & 0.121489 & \multirow{2}{*}{0.052225} \\
\hline & $(0.1826)$ & $(0.2474)$ & \\
\hline
\end{tabular}

Note: The table presents PMG estimation results controlling for global financial crisis (GCF) and euro crisis (EURO) in the baseline model. The VOL coefficients are reported as per 1,000 units and $*, * * * * *$ represent statistical significance, at the $10 \%, 5 \%$ and $1 \%$ level. ECT represents error correction term and D () represents first difference at the different lags. Three lags are chosen. 
The error-correction coefficient is significant and acceptable in both GCF and EURO models. Comparatively, the uncertainty effect of exchange rate on consumption over the long-run is similar directionally to that of baseline after controlling for the global financial crisis and euro zone crisis. Specifically, the spillover effect of euro crisis on exchange rate uncertainty is significant and higher than the effect of global financial crisis (GFC). In fact, GFC dummy variable is statistically insignificant. Incorporating the effect of euro crisis increase the influence of real income on consumption above unity and reduce the impact of natural interest rate below the baseline effect.

\section{What Component of Uncertainty Matter?}

Clearly, exchange rate uncertainty exerts adverse long-run influence on consumption. However, policy maker would be more interested in which component of uncertainty influences consumption. Literature revealed that there are different spillover effects of temporary and permanent component on the economy. Table 7a\&b shows the results using both components.

Table 7a: Permanent component

\begin{tabular}{|c|c|c|c|}
\hline Variable & Coefficient & t-Statistic & Prob.* \\
\hline \multicolumn{4}{|c|}{ Long run estimates } \\
\hline In $\mathrm{Y}$ & $0.803125^{\star * *}$ & 12.11153 & 0.0000 \\
\hline NIR & $0.017363^{* * *}$ & 4.528307 & 0.0000 \\
\hline VOL & $-1.3553^{\star * *}$ & -3.154974 & 0.0017 \\
\hline \multicolumn{4}{|c|}{ Short-run estimates } \\
\hline ECT & $-0.02206^{*}$ & -1.679548 & 0.0934 \\
\hline $\mathrm{D}(\operatorname{LCSM}(-1))$ & $-0.260389^{\star *}$ & -3.736182 & 0.0002 \\
\hline $\mathrm{D}(\operatorname{LCSM}(-2))$ & -0.085996 & -0.945545 & 0.3446 \\
\hline $\mathrm{D}(\operatorname{LCSM}(-3))$ & -0.059102 & -0.717874 & 0.4730 \\
\hline $\mathrm{D}(\mathrm{LY})$ & $0.448984^{* * *}$ & 4.735304 & 0.0000 \\
\hline $\mathrm{D}(\mathrm{LY}(-1))$ & $0.202969^{* *}$ & 2.200436 & 0.0280 \\
\hline $\mathrm{D}(\mathrm{LY}(-2))$ & 0.124116 & 1.319478 & 0.1873 \\
\hline $\mathrm{D}(\mathrm{LY}(-3))$ & 0.104852 & 1.298388 & 0.1945 \\
\hline $\mathrm{D}(\mathrm{NIR})$ & $-0.003288^{\star *}$ & -2.422490 & 0.0156 \\
\hline $\mathrm{D}(\operatorname{NIR}(-1))$ & 0.000692 & 0.726370 & 0.4678 \\
\hline $\mathrm{D}(\operatorname{NIR}(-2))$ & -0.000954 & -0.890154 & 0.3736 \\
\hline $\mathrm{D}(\operatorname{NIR}(-3))$ & -0.001929 & -1.331765 & 0.1833 \\
\hline $\mathrm{D}($ VOLT $)$ & 0.015158 & 0.102918 & 0.9180 \\
\hline $\mathrm{D}(\operatorname{VOLT}(-1))$ & $-0.028507^{\star \star \star}$ & -2.966296 & 0.0031 \\
\hline $\mathrm{D}(\operatorname{VOLT}(-2))$ & $-0.024891^{\star *}$ & -1.998081 & 0.0460 \\
\hline $\mathrm{D}(\operatorname{VOLT}(-3))$ & -0.017876 & -1.185565 & 0.2361 \\
\hline CONSTANT & $0.298017^{\star}$ & 1.670917 & 0.0951 \\
\hline
\end{tabular}

Note: Summary of results of permanent component. VOLT (i.e., permanent or temporary component VOL: here it is permanent). Table 7a displays the coefficients' estimates. The log Consumption, InC is the dependent variable. While log of income $(\ln Y), \log$ of natural interest rate (InNIR), and VOLT are the independent variables. In parentheses are the $p$-values; D and ECT represent the first difference estimator and the error-correction term respectively. The VOLT coefficients are reported as per 1,000 units and $*, * *, * * *$ represent statistical significance, at the $10 \%, 5 \%$ and $1 \%$ level and $D()$ represents first difference at the different lags. Three lags are chosen. 
Permanent and temporary uncertainties negatively influence long-run real consumption. However, in terms of magnitude, permanent component hurts consumption more than temporary component.

Table 7b: Temporary component

\begin{tabular}{|c|c|c|c|}
\hline Variable & Coefficient & t-Statistic & Prob.* \\
\hline \multicolumn{4}{|c|}{ Long run estimates } \\
\hline LY & $0.467694^{* * *}$ & 7.360383 & 0.0000 \\
\hline NIR & $0.006481^{\star * *}$ & 3.370931 & 0.0008 \\
\hline VOLT & $-0.703627^{\star * *}$ & -2.916604 & 0.0036 \\
\hline \multicolumn{4}{|c|}{ Short-run estimates } \\
\hline COINTEQ01 & $-0.030772^{\star *}$ & -2.043435 & 0.0413 \\
\hline $\mathrm{D}(\operatorname{LCSM}(-1))$ & $-0.270206^{* * *}$ & -3.704317 & 0.0002 \\
\hline $\mathrm{D}(\operatorname{LCSM}(-2))$ & -0.101201 & -1.110614 & 0.2670 \\
\hline $\mathrm{D}(\operatorname{LCSM}(-3))$ & -0.071257 & -0.859314 & 0.3904 \\
\hline $\mathrm{D}(\mathrm{LY})$ & $0.460068^{\star * \star}$ & 4.585638 & 0.0000 \\
\hline $\mathrm{D}(\mathrm{LY}(-1))$ & $0.212006^{\star *}$ & 2.102951 & 0.0357 \\
\hline $\mathrm{D}(\mathrm{LY}(-2))$ & 0.150340 & 1.550975 & 0.1212 \\
\hline $\mathrm{D}(\mathrm{LY}(-3))$ & 0.137247 & 1.518404 & 0.1292 \\
\hline $\mathrm{D}(\mathrm{NIR})$ & $-0.003606^{* * *}$ & -2.822587 & 0.0049 \\
\hline $\mathrm{D}(\operatorname{NIR}(-1))$ & 0.000663 & 0.749701 & 0.4536 \\
\hline $\mathrm{D}(\operatorname{NIR}(-2))$ & -0.000930 & -0.912645 & 0.3617 \\
\hline $\mathrm{D}(\operatorname{NIR}(-3))$ & -0.001745 & -1.288553 & 0.1979 \\
\hline D(VOLT) & $0.02648^{\star *}$ & 1.991256 & 0.0467 \\
\hline D(VOLT(-1)) & -0.00277 & -0.358272 & 0.7202 \\
\hline $\mathrm{D}(\operatorname{VOLT}(-2))$ & -0.00446 & -0.362929 & 0.7167 \\
\hline $\mathrm{D}(\operatorname{VOLT}(-3))$ & -0.00540437 & -0.322389 & 0.7472 \\
\hline CONSTANT & -0.361152 & -1.129494 & 0.2590 \\
\hline
\end{tabular}

Note: Summary of results of permanent component. VOLT (i.e., permanent or temporary component VOL: here it is temporary) Table 7a displays the coefficients' estimates. The log Consumption, $\ln C$ is the dependent variable. While log of income (InY), log of natural interest rate (InNIR), and VOLT are the independent variables. In parentheses are the $p$-values; D represent the first difference estimator. The VOLT coefficients are reported as per 1,000 units and $*, * *, * * *$ represent statistical significance, at the $10 \%, 5 \%$ and $1 \%$ level and $D()$ represents first difference at the different lags. Three lags are chosen.

\section{CONCLUSION}

Consumption is a crucial element of aggregate demand which influences other macroeconomic variables that affects growth and policy decisions. This paper has examined the impact of exchange rate volatility on real consumption in the euro zone from1995Q1 to 2019Q4. GARCH $(1,1)$ was used to assess for uncertainty while EGARCH was used to assess uncertainty asymmetry, and component GARCH was used to obtain the permanent and temporary components of exchange rate volatility.

In the benchmark model, pooled mean group (PMG) was employed to show the presence of a stable long run impact of unstable exchange rate over consumption in euro zone. However, a long run parameter estimates indicate that exchange rate uncertainty is an impediment for real consumption in the long run, while a mixed effect in the short run. 
This provides evidence to support that uncertainty impact on consumption in the euro zone is not the same in direction in the short and long run. Also, permanent uncertainty hurts consumption almost two times more than temporary uncertainty, which lends support to recent findings, for example Iyke and Ho (2019), that permanent uncertainty hurts more than temporary uncertainty. Also, real income significantly enhances consumption in both long and short run implying that, a raise in real income would induce an increase in real consumption in both periods.

By adopting the PMG estimator, the result shows that, in the euro zone, exchange rate uncertainty dampens real consumption in both long and short runs. It can be observed in the benchmark model that the error-correction coefficient is negative and highly significant, at $1 \%$ conventional statistical level, lending support to the reality of a long run impact of uncertainty of exchange rate on real consumption. The error correction coefficient value of -0.044 suggests that convergence/return to the long-run equilibrium path for consumption following an economic-wide shock (short run deviations) appears to be slow, as the proportion of disequilibrium corrected in one quarter is about $4 \%$, which implies it would take close to 17 quarters for one half of the disequilibrium (or deviations from the long run real consumption) in the eEuro zone, to become corrected.

To ensure that the results in the benchmark model are not fully reliant on the measure of uncertainty adopted, quarterly standard deviations is used as an alternative measure of uncertainty. Even with this measure, a negative long run link between uncertainty and consumption, continues to emerge, while a negative effect now dominates in the short run. Thus, while the long run effect of uncertainty on real consumption is adverse in the eEuro zone, irrespective of the measure of uncertainty adopted, there is evidence that the short run effect can be mixed. Hence, it can be conclusively said that the alternative hypothesis (H1): that there is significant impact of macroeconomic uncertainty on real consumption both in the short and long run for eurozone is accepted while null hypothesis (H0): that there is no significant impact of macroeconomic uncertainty on real consumption both in the short and long run for eurozone is rejected. That is irrespective of the mixed direction for short run as well as the negative direction for long run, macroeconomic uncertainty significantly impacts real consumption both in the short and long run for the eurozone.

Although both components require policy attention, policymakers should focus more on permanent uncertainty as evidenced from our results. As the results suggest, the dampening exchange rate uncertainty impact on consumption in the eEuro zone is mostly a long run issue, one important policy implication is that eEuro zone policy makers would do well to focus relatively less on uncertainty in the short run, but instead place much more emphasis on minimizing the dampening long-run impact of exchange rate uncertainty. One way to do this is to concentrate attention and resources on minimizing the permanent uncertainty component of uncertainty given that it has a considerably larger dampening effect on long-run consumption. 


\section{REFERENCES}

Adewuyi, A.O. \& Akpokodje, G. (2013). Exchange Rate Volatility and Economic Activities of Africa's Sub-Groups. The International Trade Journal, 27 (4), 349-384. https://doi.org/10.1080/08853908.2013.813352

Al-Abri, A. \& Baghestani, H. (2015). Foreign investment and real exchange rate volatility in emerging Asian countries. Journal of Asian Economics, 37, 34-47. https://doi.org/10.1016/j.asieco.2015.01.005

Aliyu, S. U. R. (2010). Exchange Rate Volatility and Export Trade in Nigeria: An Empirical Investigation. Applied Financial Economics, 20(13), 1071-1084. https://doi.org/10.1080/09603101003724380

Ang, J. B. (2011). Finance and consumption volatility: Evidence from India. Journal of International Money and Finance, 30(6), 947-964. https://doi.org/10.1016/j.jimonfin.2011.05.010

Arize, A. C., Malindretos, J. \& Igwe, E. U. (2017). Do Exchange Rate Changes Improve the Trade Balance: An Asymmetric Nonlinear Cointegration Approach. International Review of Economics and Finance, 49, 313-326. https://doi.org/10.1016/j.iref.2017.02.007

Asteriou, D., Masatci, K. \& Pilbeam, K. (2016). Exchange rate volatility and international trade: International evidence from the MINT countries. Economic Modelling, 58, 133-140. https://doi.org/10.1016/j.econmod.2016.05.006

Aydin, B. (2010). Exchange Rate Assessment for Sub-Saharan Economies. IMF, Working Paper 10(162), 1-32. Retrieved from: http://www.imf.org/external/pubs/ft/wp/2010/wp10162.pdf.

Aye, G. C., \& Harris, L. (2019). The effect of real exchange rate volatility on income distribution in South Africa, WIDER Working Paper, 29. Helsinki: The United Nations University World Institute for Development Economics Research (UNU-WIDER). http://dx.doi.org/10.35188/UNU-WIDER/2019/663-0.

Bachmann, R., Elstner, S. \&Sims, E. R. (2013). Uncertainty and Economic Activity: Evidence from Business Survey Data. American Economic Journal: Macroeconomics, 5(2), 217-249. http://dx.doi.org/10.1257/mac.5.2.217

Bachmann, R. and Moscarini, G. (2012). Business Cycles and Endogenous Uncertainty. Mimeo: Yale University. Retrieved from: https://cpb-us-w2.wpmucdn.com/campuspress.yale.edu/dist/1/1241/files/2017/01/ endogenous_uncertainty-1rm5a8p.pdf

Bahmani-Oskooee, M. Akhtar, P. Ullah, S. \& Majeed, M. T. (2020). Exchange Rate Risk and Uncertainty and Trade Flows: Asymmetric Evidence from Asia. Journal of Risk and Financial Management, 13(6), 128. https://doi.org/10.3390/jrfm13060128

Bahmani-Oskooee, M., Kutan, A. M. \& Xi, D. (2015). Does exchange rate volatility hurt domestic consumption? Evidence from emerging economies. International Economics, 144, 53-65. https://doi.org/10.1016/j. inteco.2015.05.002

Bahmani-Oskooee, M. \& Xi, D. (2012). Exchange rate volatility and domestic consumption: evidence from Japan. Economic Systems, 36(2), 326-335. https://doi.org/10.1016/j.ecosys.2011.10.004

Bahmani-Oskooee, M. \& Xi, D. (2011). Exchange rate volatility and domestic consumption: A multicountry analysis. Journal of Post Keynesian Economics, 34(2), 319-330. https://doi.org/10.2753/PKE0160-3477340207

Bahmani-Oskooee, M., \& Hajilee, M. (2012). On the relation between currency depreciation and domestic consumption. Economia Internazionale - International Economics, 65(4), 503-512.

Bahmani-Oskooee, M. \& Baek, J. (2020). On the asymmetric effects of the real exchange rate on domestic investment in G7 countries. Australian Economic Papers, 59(4), 303-318. https://doi.org/10.1111/1467-8454.12187

Bahmani-Oskooee, M., Halicioglu, F., \& Neumann, R. (2018). Domestic investment responses to changes in the real exchange rate: Asymmetries of appreciation versus depreciations. International Journal of Finance and Economics, 23(4), 362-375. https://doi.org/10.1002/ijfe.1621

Blagov, B. (2019). Exchange rate uncertainty and import prices in the euro area. Review of International Economics, 27(5), 1537-1572. https://doi.org/10.1111/roie.12434

Bloom, N. (2014). Fluctuations in uncertainty. Journal of Economic Perspectives, 28(2), 153-176. https://doi. org/10.1257/jep.28.2.153 
Bogut, O. \& Kuehn L. (2013). Consumption volatility risk. Journal of Finance, 68(6), 2589 - 2615. https://doi. org/10.1111/jofi.12058

Bondt, G., Giesek, A. \& Tujula, M. (2020). Household wealth and consumption in the euro area. Economic Bulletin Articles, 1. Retrieved from: https://www.ecb.europa.eu/pub/economic-bulletin/articles/2020/html/ecb. ebart2 02001_01 6ce994a1f7.en.html

Dada, J. T. (2017). Exchange Rate Volatility and Trade Balance in Sub-Saharan African Countries: A Causal Relationship. American Journal of Business, Economics and Management, 5(5), 68-73.

D’Erasmo, P.N., \& Boedo, H.M. (2012). Intangibles and Endogenous Firm Volatility over the Business Cycle. Mimeo: University of Maryland.

Fernandez-Villaverde, J., Guerron-Quintana, P., Rubio-Ramirez, J.F. \& Uribe, M. (2011). Risk Matters: The Real Effects of Volatility Shocks. American Economic Review, 101(6), 2530-2561. https://doi.org/10.1257/ aer.101.6.2530

Fostel, A. \& Geanakoplos, J. (2012). Why Does Bad News Increase Volatility and Decrease Leverage? Journal of Economic Theory, 147(2), 501-525. https://doi.org/10.1016/j.jet.2011.07.001

Gutiérrez, R., Calisto, E. O. \& Salgado, O. G. (2017). Long-term effects of the asymmetry and persistence of the prediction of volatility: Evidence for the equity markets of Latin America. Contaduría y Administración Accounting and Management, 62(4), 1081-1099. https://doi.org/10.1016/j.cya.2015.12.004

Hegerty, S. W. (2020). Macroeconomic volatility, monetary union, and external exposure: evidence from five Euro zone members, Baltic Journal of Economics, 20(2), 117-138. https://doi.org/10.1080/1406099X.2020.1780694

Herve, D. B., Yao, S. \& Amzath, A. (2010). The Effects of Real Exchange Rate on Trade Balance in Cote d'Ivoire: Evidence from the Cointegration Analysis and Error-Correction Models, 21810. Muenchen: Munich Personal RePEc Archive.

Iyke, B. N., \& Ho, S. Y. (2019). Consumption and exchange rate uncertainty: Evidence from selected Asian countries. The World Wconomy, 43(9), 2437-2462. https://doi.org/10.1111/twec.12900.

Iyke, B. N. (2018). Macro Determinants of The Real Exchange Rate in a Small Open Small Island Economy: Evidence from Mauritius Via BMA. Buletin Ekonomi Moneter Dan Perbankan, 21(1), 57-80. https://doi. org/10.21098/bemp.v21i1.922

Johannes, M., Lochstoer, L.A. \& Mou, Y. (2016). Learning about Consumption Dynamics. Journal of Finance, 71(2), 551-600. https://doi.org/10.1111/jofi.12246

Kandil, M. \& Mirzaie, A. (2011). Consumption, Credit, and Macroeconomic Policies: Theory and Evidence from the United States. Global Economic Review, 40(3), 323-360. https://doi.org/10.1080/1226508X.2011.601645

Kim, C. B. (2017). Does Exchange Rate Volatility Affect Korea's Seaborne Import Volume? The Asian Journal of Shipping and Logistics, 33(1), 43-50. https://doi.org/10.1016/j.ajsl.2017.03.006

Kodama, M. (2013). External shocks and high volatility in consumption in low-income countries, The Developing Economies. 51(3), 278-302. https://doi.org/10.1111/deve.12019

Köse, N. \& Aslan, C. (2020). The effect of real exchange rate uncertainty on Turkey's foreign trade: new evidences from SVAR model. Asia-Pacific Journal of Accounting and Economics. Unpublished manuscript. https:// doi.org/10.1080/1608/1625.2020.1808798

Kugler, P. (1985). Autoregressive modelling of consumption, income, inflation and interest rate data: A multicountry study. Empirical Economics, 10(1), 37-50. https://doi.org/10.1007/BF01988281

Kumar, A., Bhutto, N. A., Mangrio, K. A. \& Kalhoro, M. R. (2019). Impact of external debt and exchange rate on Domestic Consumption: New Evidence from Pakistan. Cogent Economics and Finance, 7(1), 1568656. https://doi.org/10.1080/23322039.2019.1568656

Latief, R. \& Lefen, L. (2018). The Effect of Exchange Rate Volatility on International Trade and Foreign Direct Investment (FDI) in Developing Countries along "One Belt and One Road". International Journal of Financial Studies, 6(4), 86. https://doi.org/10.3390/ijfs6040086

Campbell, J. Y. \& Mankiw, G. N. (1991). The response of consumption to income A cross-country investigation. European Economic Review, 35(4) 723-756. https://doi.org/10.1016/0014-2921(91)90033-F 
Mumtaz, S. \& Ali, M. (2020). Impact of exchange rate and its volatility on domestic consumption in India and Pakistan. Journal of Public Affairs. Unpublished manuscript. https://doi.org/10.1002/pa.2479.

Nelson, D. (1991). Conditional Heteroskedasticity in Asset Returns: A New Approach. Econometrica, 59(2), 347370. https://doi.org/10.2307/2938260

Njindan Iyke, B. \& Ho, S. Y. (2018). Real Exchange Rate Volatility on Domestic Consumption in Ghana. Journal of Risk Finance, 19(5), 513-523. https://doi.org/10.1108/JRF-01-2017-0010

Nodir, B. (2011). The Exchange Rate Volatility and the Trade Balance: Case of Uzbekistan. Journal of Applied Economics and Business Research, 1(3),149- 161. Retrieved from: http://www.aebrjournal.org/uploads/6/6/2/2/6622240/paper_3.pdf

Obstfeld, M. \& Rogoff, K. (1998). Risk and exchange rates. NBER Working Papers, 6694. Cambridge, MA: National Bureau of Economic Research.

Okwu, A.T., Akpa, E.O., Oseni, I.O. \& Obiakor, R.T. (2020). Oil Export Revenue and Exchange Rate: An Investigation of Asymmetric Effects on Households' Consumption Expenditure in Nigeria, Babcock Journal of Economics, 7, 13-28. Retrieved from: https://mpra.ub.uni-muenchen.de/id/eprint/102080

Olomola P. A. \& Dada, J. T. (2017). Real Exchange Rate, Exchange Rate Volatility and Trade

Balance in Sub-Saharan African Countries: A Generalized Method of Moment (GMM) Approach. International Journal of Scientific Research and Management, 5(11), 7395-7403. https://doi.org/10.18535/ijsrm/v5i11.08

Oseni, I. O. (2016). Exchange rate volatility and private consumption in Sub-Saharan African: A system- GMM dynamic panel analysis. Future Business Journal, 2(2), 103-115. https://doi.org/10.1016/j.fbj.2016.05.004

Palumbo, M., Rudd, J. \& Whelan, K. (2002). On the Relationships Between Real Consumption, Income, and Wealth. Research Technical Papers, 4/RT/02. Dublin: Central Bank of Ireland.

Pavlidis, E.G., Paya, I \& Peel, D.A. (2015). Testing for Linear and Nonlinear Granger Causality in the Real Exchange Rate-Consumption Relation. Economics Letters, 132, 13-17. https://doi.org/10.1016/j.econlet.2015.04.008

Pesaran, M., \& Shin, Y. (1999). An Autoregressive Distributed-Lag Modelling Approach to Cointegration Analysis. In S. Strøm (Ed.), Econometrics and Economic Theory in the 20 $0^{\text {th }}$ Century: The Ragnar Frisch Centennial Symposium (Econometric Society Monographs, pp. 371-413). Cambridge: Cambridge University Press. https://doi.org/10.1017/CCOL521633230.011.

Pham, T. H. M. \& Nasir, M. A. (2016). Conspicuous consumption, luxury products and counterfeit market in the UK. The European Journal of Applied Economics, 13(1), 72-83. https://doi.org/10.5937/ejae13-10012

Rangvid, J., Santa-Clara, P., \& Schmeling, M. (2016). Capital market integration and consumption risk sharing over the long Run. Journal of International Economics, 103, 27-43. https://doi.org/10.1016/j.jinteco.2016.08.001

Rania A. A. (2015). Effects of Real Exchange Rate Volatility on Jordanian International Trade. Current Research Journal of Economic Theory, 7 (1), 11-13. http://dx.doi.org/10.19026/crjet.7.2110

Soleymani, A. \& Chua, S. Y. (2014). Effect of exchange rate volatility on industry trade flows between Malaysia and China. The Journal of International Trade \& Economic Development an International and Comparative Review, 23(5), 626-655. https://doi.org/10.1080/09638199.2013.803146

Šovran, S. \& Hadžić, M. (2016). Contemporary forms of international movement of capital. The European Journal of Applied Economics, 13(2), 1-9. https://doi.org/10.5937/ejae13-10617

Tang, D. (2020). Have Export Compositions Influenced Economic Growth of the European Union Countries in Central and Eastern Europe? The European Journal of Applied Economics, 17(1), 80-103. https://doi. org/10.5937/EJAE17-23638

Tendogap, R. (2015). Consumption Volatility and the Cross-Section of Stock Returns. Review of Finance, 19(1), 367-405. https://doi.org/10.1093/rof/rtt058

Tian, C. (2012). Technology Choice and Endogenous Productivity Dispersion over the Business Cycles. Mimeo: University of Pennsylvania.

Yaya M. E. \& Lu X. (2012). The Short-Run Relationship between Real Effective Exchange Rate and Balance of Trade in China, International Journal of Applied Economics, 9(1), 15-27. Retrieved from: https://www2. southeastern.edu/orgs/ijae/index_files/IJAE\%20MARCH\%202012\%20YAYA\%20LU\%204-30-2012.pdf 


\section{DOMAĆA POTROŠNJA I NEIZVESNOST DEVIZNOG KURSA U MONETARNOJ UNIJI: DOKAZI IZ EVROZONE}

\section{Rezime:}

Istraživanje pokušava da otkrije kako realna potrošnja kratkoročno i dugoročno reaguje na neizvesnost deviznog kursa za najveću svetsku monetarnu uniju - evrozonu. Dvanaest zemalja evrozone je uzorkovano za period 1995Q1-2019Q4. Koristeći generalizovanu autoregresivnu uslovnu heteroskedastičnost (GARCH) i objedinjenu srednju grupu, rezultati pokazuju da nesigurnost deviznog kursa značajno umanjuje dugoročnu potrošnju dok je kratkoročni efekat pomešan. U referentnom modelu dobijen je negativan i značajan koeficijent korekcije greške, što omogućava argument da i) postoje dokazi o povratku na dugoročni ravnotežni put potrošnje nakon kratkoročnih odstupanja i ii) brzina prilagođavanja ravnoteži je niska, sa koeficijentom od 4\%. To sugeriše da je u evrozoni konvergencija ka dugoročnoj ravnoteži spora, jer je procenat neravnoteže korigovane $\mathrm{u}$ jednom kvartalu, nakon šoka, oko $4 \%$, što znači da bi za polovinu neravnoteža ili odstupanja od dugoročne putanje potrošnje koja treba da se isprave trebalo $\sim 17$ kvartala.
Ključne reči:

Monetarna unija, evrozona, devizni kurs, potrošnja, nesigurnost, GARCH, PMG.

Klasifikacija jela: E20, E21 